\title{
Economic and Financial Profitability: A Comparative Study between Islamic and Conventional Banks during the Current Crisis
}

Ferhi $A^{*}$

Higher Institute of Management of Tunis, Tunisia

\begin{abstract}
This research consists in studying the economic and financial profitability of Islamic and conventional banks in 23 countries during the current crisis. For this purpose, we use a sample of 99 Islamic and 110 conventional banks during the 2005/2015 period. The Generalized Least Squares (GLS) dynamic panel is applied to measure the difference between Islamic and conventional banks in terms of economic and financial returns. The results showed that during the period of the financial crisis, the financial profitability of Islamic and traditional banks falls. Our results also demonstrated that the financial crisis adversely affects the profitability of conventional banks more than that of Islamic banks.
\end{abstract}

Keywords: Financial profitability; Economic profitability; Islamic banks; Conventional banks

\section{Introduction}

Islamic finance is above all, an ethical finance, which favors a system of values based on the need to move away from what is forbidden, on a balance between personal and public interest as well as on values of integrity, transparency and honesty. These values are of crucial importance and therefore must be reflected in acts and transactions.

Islamic finance is based on the notion of justice, which is essentially assured by the sharing of risk. The different actors are supposed to share their profits and losses. In fact, all forms of interest are "riba" and hence they are prohibited. Unlike traditional intermediation, which relies mainly on indebtedness and allows a transfer of risk, Islamic intermediation is based on asset pledging and risk sharing. In other words, for Islamic banks, investments are structured around the exchange or appropriation of an asset; therefore, they are closer to the real economy than the traditional banks that can create mainly notional or virtual products. The Islamic financial institutions manage more than 1000 billion US dollars in the world and are developing at a rapid pace. They attract even more attention because they appear to have resisted the current crises better than their "conventional" counterparts. These financial and economic crises are considered the most devastating since 1929 .

The current financial crisis started in the sub-prime mortgage sector in the United States and spread to trigger a financial crash in the fall of 2008 that shook the international stock markets, pillaged the pillars of global finance, and Led to a recession affecting the entire planet. This crisis inflicted a new damage and victims around the world to the point of marking the annals of the major financial crises in history and of arousing the curiosity of a good number of analysts and economists. It is in fact an opportunity to review the current foundations of the international financial system, characterized, in particular, by an excess of financialization which distinguishes the real economy from the financial one and encourages the indebtedness and the speculative drifts, which weakens the system and exposes it to more crises in the future.

The "Subprime" Credit highlighted Islamic finance and presented it as a means of regulating the world economy, especially after the many weaknesses that the traditional finance has experienced. In this fragile macroeconomic context, the sentiment of the financial markets fluctuated according to the actions of the authorities.
The global financial crisis of 2008-2009, as well as the deep recession, caused a set of macroeconomic imbalances in the Euro zone, such as the unbearable positions in public finances, the excessive increase of private indebtedness, as well as significant shortcomings in competitiveness in some member States. Moreover, they revealed weaknesses in the institutional framework of Economic and Monetary Union (EMU). The inadequacy of the monitoring and coordination mechanisms of economic policies had indeed enabled these imbalances to expand in different countries.

With the enormous losses caused by the crisis, most of the world turned first to ethical finance and then to Islamic finance which proved its evidence during the subprime crisis [1-3].

In this environment characterized by the onset of financial and economic crises, financial institutions must take all the measures they need to improve their economic and financial profitability. These financial institutions are essential for any nation in order to ensure a healthy economy that responds to the needs and aspirations of the major economic factors that make up that economy. They fulfill a considerable number of important functions for the economy.

We observe that, in an unstable economic environment, attention is gradually shifting towards Islamic financing techniques since the financial system based on Shari'a principles shows stability and resistance to the failures of the conventional system. For this reason, it has become imperative for Islamic banks to boost their profitability in order to take advantage of this opportunity.

Several authors focused on the resistance of Islamic banks in times of economic crisis, while others compared the profitability of Islamic and traditional banks in 2008 [4-6]. Some authors showed that Islamic banks perform better than conventional ones in times of crisis. Others

*Corresponding author: Ferhi A, Ph.D, Higher Institute of Management of Tunis, 41, Avenue de la Liberté, Cité Bouchoucha, Le Bardo 2000 - Ave de la Liberte, Tunis 2000, Tunisia, Tel: +216 71588 514; E-mail: ferhi_afifa1983@yahoo.fr

Received July 18, 2017; Accepted August 01, 2017; Published August 10, 2017

Citation: Ferhi A (2017) Economic and Financial Profitability: A Comparative Study between Islamic and Conventional Banks during the Current Crisis. Intel Prop Rights. 5: 189. doi: 10.4172/2375-4516.1000189

Copyright: @ 2017 Ferhi A. This is an open-access article distributed under the terms of the Creative Commons Attribution License, which permits unrestricted use, distribution, and reproduction in any medium, provided the original author and source are credited. 
argued that, on the contrary, conventional banks have suffered less from the crisis. Finally, others did not see any significant difference in performance between the different types of banks due to the crisis. Among the authors who claimed that Islamic banks have performed better, we can cite [3,7]. According to the latter, "the profitability of Islamic banks remains less volatile and probably higher than that of conventional banks" [7].

There are two main contributions of our study. First, it complements the previous literature that describes the level of profitability of Islamic and conventional banks [8-10]. Second, the study period of the banking sector situation involves the recent subprime and the Euro zone crises, unlike other documents which describe the phenomenon during a single attack. Besides, we are motivated by the fact that there is no study that has examined the economic and financial profitability of Islamic and usurious banks during the current crisis using the shock variable.

The rest of the paper is organized as follows: Part 2 presents a review of the literature, while part 3 discusses the data and methodologies applied and part 4 illustrates and evaluates the results of the empirical analysis. Finally section 5 concludes the paper.

\section{Literature Review}

Alongside the growing interest in Islamic finance, the literature on Islamic finance has grown rapidly. In fact, a significant number of investigations have examined the profitability of Islamic banks.

Bashir [11] examined the performance of Islamic banks in the Middle East region between 1993 and 1998. To measure the profitability, he used the net interest margin (NIM), the income before tax (BTP), the returns on the invested assets (ROA) and the returns on equity (ROE). The results confirmed the previous findings and showed that the profitability of Islamic banks is positively related to both equity and loans. These results also indicated that the favorable macroeconomic conditions positively impact profitability.

Hassoun [7] compared the "ROA" and "ROE" for both Islamic and conventional banking sectors in three GCC countries, Kuwait, Saudi Arabia and Qatar. His findings showed that Islamic banks are more profitable than their conventional peers.

According to Sanaullah Ansari and Atiq Rehman [8], the performance of the first Islamic bank in Pakistan, Meezan Bank, has been compared to a group of five conventional banks. The study evaluated the banking performance in terms of profitability, liquidity, risk and efficiency over the 2003/2007 period. Twelve financial ratios, such as, return on invested assets (ROA), return on equity (ROE), loan to deposit ratio (LDR), loan to total asset ratio (LAR), capital ratio (DE), the use of the asset ratio (AU) and spending on income ratio (IER), were used as variables to assess the bank's performance. The study also revealed that the Islamic bank (MBL) is less profitable, but more solvent (less risky), and also less efficient compared to the average of the five conventional banks.

On the other hand, Siddiqui analyzed the behavior of Islamic and conventional financing model, and found that Islamic banks in Pakistan were more inclined to fund long term employees' projects and that the profitability of Islamic banks is higher than that of conventional banks. However, Sadaqat and Akhtar [12] reported a superior performance of conventional banks.

Noor found that Islamic banks were administratively unable to take advantage of their resources in the optimal extent. Jafar and Manarvi [13] examined the performance of conventional and Islamic banks in
Pakistan between 2005 and 2009. They found that conventional banks are more able to attract profits and risk management than Islamic banks. However, they noted that Islamic banks have greater liquidity and a more adequate capital than conventional banks.

In the same vein, Ansari and Rehman [9] used data over the 2006/ 2009 period of three Islamic and three conventional banks to measure the difference between these two banking institutions in terms of performance. By using the return on assets, return on equity, profit margin and expenses to measure profitability, it appeared that there is no significant difference between both types of banks.

Similarly, Sehrish [14] analyzed and compared the profitability of 4 Islamic banks and 4 conventional banks in Pakistan during the $2007 / 2011$ period. They found that there is no significant difference between the two banking sectors.

On the other hand, the study of Siraj and Sudarsanan [15], which discussed the profitability of 6 Islamic banks and 6 conventional banks in the countries of the Gulf Cooperation Council between 2005 and 2009, showed that the Islamic banks are more profitable than the conventional ones.

In the same context, Usman and Khan [10] compared Islamic and conventional banks' performance over the $2007 / 2009$ period. They used the profitability and liquidity ratios of Islamic and conventional banks. Their results showed that Islamic banks have a rate of growth, profitability and liquidity higher than that of conventional banks.

Abedifar [16] pointed out that the principle of profit and loss sharing offers a pro-cyclical protection to banks in case of adverse conditions. They also said that religious depositors may be more loyal and willing to take lower returns, refusing to withdraw deposits, even though the bank's performance deteriorates. Therefore, the profitability of Islamic banks is less volatile than that of conventional banks.

In addition, Abedifar [16] argue that religiosity may also influence the bank's performance by encouraging borrowers to meet their obligations in accordance with Islamic loan contracts. Indeed, clients with religious beliefs are more likely to prefer Islamic banks than conventional ones and therefore are willing to pay rents to receive financial services consistent with their religious beliefs [16].

A positive relationship between profitability and banking capital has been reported in previous empirical studies [17-19]. Therefore, given that Islamic banks employ more capital than their conventional counterparts in financing their assets, the profitability of banks is more likely to be higher for Islamic banks.

The main empirical results of previous studies showed that Islamic banks are more profitable than conventional ones [16,20-22].

\section{Methodologies}

\section{Model}

Several authors, such as Pasiouras [18], Van Horen among others, argued that returns on assets (ROA) are the most useful measurements of the profitability over time because the assets have a direct effect on the revenue and expenses. However, the ROE can also be an important measure of profits in many cases.

The models explaining the ROA and ROE are estimated using a panel of Generalized Least Squares estimator. The panel models of the basic framework are:

$$
Y_{i t}=\alpha_{i}+\beta_{i t}+\varepsilon_{i t} \text { with }(i=1, \ldots 209 \text { and } t=2005, \ldots 2015)
$$


Citation: Ferhi A (2017) Economic and Financial Profitability: A Comparative Study between Islamic and Conventional Banks during the Current Crisis. Intel Prop Rights. 5: 189. doi: 10.4172/2375-4516.1000189

Page 3 of 6

Where $\mathrm{Y}_{\mathrm{it}}$ is the dependent variable (ROA or ROE), $\alpha_{\mathrm{i}}$ is the point of intersection of the specific company in the fixed effects models while the common intersection with random variation between banks in the random effects model is a vector of the described explanatory variables, $\beta$ is a vector of regression coefficients, and ${ }^{\varepsilon}$ it is the error term.

\section{Definition of variables}

General Definition of variables is given in Table 1.

\section{The Results of the Empirical Analysis}

Empirical tests were performed to measure and examine the relationship between profitability and targeted banks. This study tests the determinants of efficiency of Islamic and conventional banks. This is done using common templates for all the countries that exist in the study, such as Saudi Arabia, Bahrain, Egypt, Iran, Jordan, Kuwait, Malaysia, Sudan, the United Arab Emirates, Yemen, Qatar, Pakistan, Bangladesh, Tunisia, Turkey, Indonesia, Singapore, the Palestinian territory, Gambia, Syria, Thailand, Lebanon and Mauritania. The determinants of banking profitability are examined using two dependent variables (ROA and ROE). As a first step of our analysis, we will estimate the first accounting model by

\section{The results of the descriptive analysis}

Explaining the two variables (ROA and ROE) of financial performance based on the loan, inefficiency, inflation, credit risk, capitalization, and the shock variables Table 2.

The results in the table below indicate that, on average, the value of the ROA in the context of conventional banks is 0.024 while that of Islamic banks is 0.03 . Therefore, based on the average value, one can say that the Islamic model is more suitable for the economic profitability in the context of our work. However, when comparing the margin between the two means, it seems that with only one value of 0.006 , the contribution of the Islamic banks to the improvement of economic profitability is not more important than that of the conventional banks.

For the ROE variable, the values of the highlighted averages in this table show that Islamic banks are more able to sustain profitability and financial stability than their conventional counterparts with a margin of 0.1 . The ROE profitability expresses the point of view of the shareholders, highlights the returns on their investment, and provides guidance on banking stability. Therefore, by comparing the contribution of IB and $\mathrm{CB}$, we can say that the contribution of IB is greater that of $\mathrm{CB}$. This leads us to point out that, in general, most IB maintain a financial viability in the economic system of our study.

With a value of "Inefficiency" equal to 0.26 , one can deduce that Islamic banks are more efficient than their usurious counterparts. Based on the values of the average "credit risk" variable, we can emphasize that usurious banks' credit risk is higher than that of Islamic banks.

Regarding the two variables, "capitalization" and "loan", the average values in conventional banks are slightly lower than those in Islamic banks.

\section{The results of the descriptive analysis by region}

The table below illustrates the descriptive statistics per region for

\begin{tabular}{|c|c|c|}
\hline & Variables & Definitions \\
\hline \multicolumn{3}{|c|}{ Dependent variables } \\
\hline ROA & $\begin{array}{l}\text { The return on asset ratio or "return on assets" also } \\
\text { called the (ROA), is the profit to asset ratio }\end{array}$ & $\begin{array}{l}\text { It is an essential indicator of the profitability of a bank. It designates the ability of the } \\
\text { administration of a credit institution to effectively manage the resources. }\end{array}$ \\
\hline ROE & $\begin{array}{l}\text { The return coefficient or "return on equity", also } \\
\text { known as the financial profitability (ROE), means the } \\
\text { earnings to equity ratio. }\end{array}$ & $\begin{array}{l}\text { The "return on equity" provides guidance on the earning power of a bank and the } \\
\text { profitability of capital invested by shareholders as it highlights the profitability of their } \\
\text { investment. }\end{array}$ \\
\hline \multicolumn{3}{|c|}{ Independent variables } \\
\hline Loan & $\begin{array}{l}\text { The "loan" variable is measured by the total net loan } \\
\text { to total asset ratio. }\end{array}$ & $\begin{array}{l}\text { A loan involves a redistribution of financial assets between the lender and the borrower } \\
\text { over time. As in most studies, profitability increases with the loan specialization ratio } \\
\text { (loans) because loans offer higher returns than other assets. }\end{array}$ \\
\hline Inefficiency & $\begin{array}{l}\text { Efficiency is measured by the ratio of operating } \\
\text { expenses to gross income. }\end{array}$ & $\begin{array}{l}\text { The literature often involves inefficiency of banks to the deterioration of the quality of } \\
\text { their assets, under-capitalization, excessive taking and mismanagement risk. }\end{array}$ \\
\hline Capitalization & $\begin{array}{l}\text { Capitalization is usually measured by the equity ratio } \\
\text { to assets. }\end{array}$ & It is the ratio of capital and reserves of banks relative to their total assets. \\
\hline Inflation & & $\begin{array}{l}\text { Inflation affects the banking sector through its influence on the bank credit market. } \\
\text { Indeed, an increase of inflation rate leads to a decrease of the real rate of return, which } \\
\text { will consequently affect the credit market and therefore the banking profitability. }\end{array}$ \\
\hline Shock & & We define shock $=0$ during the $2005-2007$ period and shock=1 for the $2008-2015$ period. \\
\hline Credit risk & $\begin{array}{l}\text { Credit risk is generally measured by the ratio of } \\
\text { provisions for losses to net loans }\end{array}$ & $\begin{array}{l}\text { It is the inability of the borrower to pay the accrued interest or repay the principal loan } \\
\text { according to the terms specified in the credit agreement. }\end{array}$ \\
\hline
\end{tabular}

Table 1: General Definition of variables.

\begin{tabular}{|c|c|c|c|c|c|c|c|c|}
\hline & \multicolumn{4}{|c|}{ Conventional banks } & \multicolumn{4}{|c|}{ Islamic banks } \\
\hline & Mean & SD & Min & Max & Mean & SD & Min & Max \\
\hline ROA & 0.024 & 0.11 & $2.3^{\mathrm{e}-06}$ & 1.45 & 0.03 & 0.06 & $5.7^{\mathrm{e}-06}$ & 0.94 \\
\hline ROE & 0.21 & 0.37 & $7.9^{\mathrm{e}-06}$ & 7.78 & 0.31 & 1.06 & 0.008 & 22.5 \\
\hline Inflation & 7.15 & 7.95 & 0.23 & 86.64 & 5.03 & 4.57 & 0.024 & 53.2 \\
\hline Loan & 44.22 & 44.62 & 2.20 & 125.1 & 45.65 & 44,7 & 3.50 & 122.3 \\
\hline Capitalization & 0.150 & 0.148 & 0.009 & 1.96 & 0.290 & 0.32 & 0.0007 & 5.173 \\
\hline Credit risk & 0.12 & 0.262 & $3.6^{\mathrm{e}-06}$ & 2.616 & 0.11 & 0.30 & $1.00^{\mathrm{e}-07}$ & 4.33 \\
\hline Inefficiency & 0.377 & 0.428 & 0.00001 & 7.5 & 0.263 & 2.68 & 0.0001 & 3.362 \\
\hline
\end{tabular}

Table 2. Descriptive statistics. 
the two indicators of banking profitability (ROA, ROE) used in our empirical investigation. By examining the average values of the two ratios "ROA" and "ROE", it can be pointed out that the economic and financial profitability of Islamic and conventional banks is higher in the countries of the Gulf Cooperation Council (GCC) than that in those of South West Asia and North Africa (Table 3).

This result can be explained by the fact that the GCC countries produce about $23 \%$ of the world's oil and control more than $40 \%$ of the world's oil reserves. On average, oil accounts for more than $80 \%$ of the export earnings and budget revenues. Over the past 6 years, the GCC revenues have considerably increased due to rising oil prices. As a result, the economies of these countries showed growth rates above the world's average, and are in a relatively strong position.

Similarly, among the main causes of the increase of the economic and financial profitability of the Gulf Cooperation Council (GCC) countries' banks, compared to other countries, is that the GCC countries have quite a large number of banks with an extensive network of subsidiaries. The banks in these countries are financially sound, well capitalized and have adopted modern banking services (Sraïri) [23]. The local banks meet the international accounting standards and the central monetary authorities of the Gulf countries have strengthened the prudential standards in recent years.

Finally, important groups of banking services, which have grown rapidly in the GCC countries, are the Islamic financial services. In 2007, the Gulf States captured about 35\% (178 billion \$) of the total assets of Islamic banks. These are mainly concentrated in Bahrain, Kuwait and the United Arab Emirates. In addition, the Islamic banking concept has also developed to cover the activities of other types of financial institutions, including the insurance, investment and fund management companies. In addition, to take advantage of Islamic financial instruments, many conventional banks in the GCC countries have added Islamic banking services to their regular banking operations.

\section{The ROA estimation model}

The panel data estimation requires, above all, the checking of the nature of the model in question: a fixed or random effects model. For the fixed effect test, the value of the computed Fisher's statistics is equal to 13.045 . At $5 \%$, tabulated Fisher's statistics indicate a value of 1 . The calculated broad value rejects the null hypothesis in favor of the fixed effect model.
Let us now turn to the random effect test where we test the two effects per individual (banks) and per period (years). Indeed, the Breush and Pagan's LM test indicates an accumulated value of 3259.7, which is much greater than the tabulated value $5 \%$. This shows that the null hypothesis of randomness per individual is widely rejected.

As a final step, we applied the Hausman test between a random effect model and a fixed effect model. In our model, the Hausman test statistics indicates a value of 3.55 with a probability of 0.62 . This implies that we must accept the null hypothesis, in other words, the random effect model is accepted. Finally, it remains for us to verify the existence of a likelihood of heterogeneity. Indeed, the Wald test indicates a value of $7.1 \mathrm{e} 7$ with a zero probability. This obviously shows the existence of a strong heterogeneity between the banks of our sample. For the ROA variable, estimating the random effect model has led to the result in Table 4.

In reviewing this table, we note that the 'shock' variable has a negative and statistically significant impact on the ROA in both Islamic and conventional banks at $1 \%$. Therefore, from these results, it seems that during the $2007 / 2015$ period, which was characterized by the onset of the subprime crisis followed by the Euro zone crisis, the economic profitability of both types of banks decreased. Similarly, the values of coefficients $(\beta)$ showed a difference in terms of shock effect on the economic profitability both types of banks in favor of Islamic banks in the order of 0.012 .

In parallel, the results indicate that, the "credit risk" variable has a significant and negative effect on the profitability of banks at $1 \%$. Comparing Islamic banks to their usurious counterparts, we can affirm that credit risk adversely affects the economic profitability of conventional banks more than that of Islamic banks. Therefore, our results are consistent with those of the studies of Coyle, Pirner and Ferhi [24-26].

In the same context, we noted that the "capitalization" variable has a positive and statistically significant effect on the economic profitability of the two banking sectors. A magnitude of 0.124 implies that a $1 \%$ increase of capital increases the profitability (ROA) of Islamic banks in the order of 0.12 , while a magnitude of 0.041 means that a $1 \%$ increase of the capital increases the (ROA) profitability of conventional banks by about 0.04 . Based on coefficients $(\beta)$, we just emphasize that this variable affects both banking sectors but in a higher manner within the Islamic banks.

The effect of the "inefficiency" variable on the phenomenon of

\begin{tabular}{|c|c|c|c|}
\hline & Islamic Banks & & Conventional Banks \\
\hline & Mean GCC & Mean Other countries & Mean GCC \\
\hline ROA & 0.0415821 & 0.02325471 & 0.0156254 \\
\hline
\end{tabular}

Table 3: Descriptive statistics per region.

\begin{tabular}{|c|c|c|c|c|c|c|}
\hline \multirow[b]{2}{*}{ ROA } & \multicolumn{3}{|c|}{ Islamic banks } & \multicolumn{3}{|c|}{ Conventional banks } \\
\hline & Coefficients & Tde Student & p-value & Coefficients & Tde Student & p-value \\
\hline Shock & -0.002721 & -3.21 & $0.002^{*}$ & -0.015155 & -2.73 & $0.004^{*}$ \\
\hline Inflation & -0.000432 & -0.33 & 0.184 & -0.000619 & -1.87 & $0.062^{+*+*}$ \\
\hline Loan & 0.0314939 & 2.54 & $0.011^{\star}$ & 0.0370975 & 2.10 & $0.036^{* *}$ \\
\hline Capitalization & 0.1248579 & 5.95 & $0.002^{*}$ & 0.041872 & 3.10 & $0.002^{*}$ \\
\hline Credit risk & -0.013011 & -4.07 & $0.003^{*}$ & -0.121127 & -2.67 & $0.008^{*}$ \\
\hline Inefficiency & -0.005796 & -0.85 & 0.396 & -0.249527 & -0.82 & 0.410 \\
\hline
\end{tabular}

Notes ${ }^{*},{ }^{* *}$ and ${ }^{* *}$ indicate a significance at $1 \%, 5 \%$, and $10 \%$, respectively. 
the study remains insignificant, while the "ready" variable shows a significant but negative effect on the economic performance of conventional banks at $1 \%$. Similarly, the value of the "Loan" variable has a positive and statistically significant effect on the economic profitability in Islamic and conventional banks at 5\%. The positive effect of the "Loan" variable on profitability remains higher in the conventional banking sector.

The table above also shows that the inflation rate has a significant but negative impact on conventional banks at $10 \%$, while for the IB, it is not significant.

\section{The ROE estimation model}

The Verification of the nature of the model is also essential for the ROE, therefore it should be examined (fixed effect model or random effect model).

Regarding the fixed effect test, the value the Fisher's statistics is equal to 4.03 . At $5 \%$, Fisher's tabulated statistics shows a value equal to 1. The calculated value accepts the null hypothesis in favor of the fixed effect model.

Let us now turn to the random effect test where we test the two effects per individual (banks) and per period (years). Indeed, the Breush and Pagan's LM test indicates an accumulated value of 540.4, which is much higher than the tabulated one, $5 \%$. This shows that the null hypothesis of randomness per individual is widely rejected.

In a last step, we applied the Hausman test between a random and a fixed effect model. In our model, the Hausman test statistics indicates a 15.38 value with a probability of 0.001 . This implies that we must reject the null hypothesis, that is, we accept a fixed effect model.

Finally, it remains for us to verify the existence of a likelihood of heterogeneity. Indeed, the Wald test indicates a value of 1 e9 with zero probability. This obviously shows the existence of a strong heterogeneity between the banks of our sample. Regarding the ROE variable, the estimation of the random effect model led to the result in Table 5.

The diagnosis of the above table shows that the "shock" variable significantly and negatively affects the financial profitability of conventional and Islamic banks. Thus, it can be stressed that during the period of the financial crisis, the financial profitability of Islamic and traditional banks declines. The values of the coefficients $(\beta)$ of both financial sectors show that the profitability of conventional banks is higher than that of their Islamic counterparts. These results can be explained by the fact that, for Islamic banks, compensation under the Mudaraba and Musharaka contract is not fixed in advance but depends on the results achieved downstream of the financing transaction.

However, for other operations, such as sales of goods or services on credit (Murabaha, Ijarah in the Salam and Istisnaâ), compensation is part of the sales price, besides, the contracts are real and far from the development of the mortgage loans, which is not the case for conventional banks.

The "loan" variable has a significant and positive effect on the financial profitability "ROE" of both banking sectors. The magnitude of 0.038 implies that a $1 \%$ increase in lending by Islamic banks increases the financial profitability of conventional banks in the order of 0.038 , while a magnitude of 0.0397 implies that a $1 \%$ increase of the lending of conventional banks increases the profitability of Islamic banks in the order of 0.039 .

However, for other operations, such as sales of goods or services on credit (Murabaha, Ijarah in the Salam and Istisnaâ), compensation is part of the sales price. For this reason, we cannot talk about a financial shock in the IB since the contracts are real and far from the development of the mortgage loans, which is not the case for conventional banks.

At 5\%, the "credit risk" variable has a significant and negative effect on the financial profitability of both Islamic and conventional financing. Based on the values of coefficients $(\beta)$, we can deduce that the Islamic banks' credit risk is higher than that of $\mathrm{CB}$. Referring to these results, we note that the increase of debt, even if it provides a higher financial return, corresponds to an additional risk taking for shareholders.

The "capitalization" variable has a significant and positive effect on the phenomenon of study. Based on the effect of coefficient ( $\beta$ ), we can say that this variable has a positive effect on the financial profitability in an Islamic financing framework than in conventional financing one.

However, the results presented in this table point out to a significant and negative effect of "inflation" on the financial profitability of conventional banks, while there is no effect on the financial profitability of Islamic banks. This further improves the result highlighting that Islamic banks do not participate or influence the inflation problem because they are not integrated in the open market mechanism usually performed between the central bank and conventional banks.

Based on the values shown in the table below, we can see that the "loan" variable has a significant and positive effect on the financial profitability of Islamic and conventional banks. Based on the coefficients, we can emphasize that the "loan" variable positively influences the financial profitability of conventional banks in a higher way than that of their Islamic counterparts.

\section{Conclusion}

The objective of this study is to compare the economic and financial profitability of Islamic and conventional banks during the current subprime crisis and that of the Euro zone using panel data models from 23 developing countries, and 209 banks (99 Islamic and 110 conventional banks) over the 2005/2015 period.

\begin{tabular}{|c|c|c|c|c|c|c|}
\hline \multirow[b]{2}{*}{ ROE } & \multicolumn{3}{|c|}{ Islamic banks } & \multicolumn{3}{|c|}{ conventional banks } \\
\hline & Coefficients & Tde Student & p-value & Coefficients & Tde Student & p-value \\
\hline Shock & -.0006463 & -1.79 & $0.073^{* * *}$ & -0.1162052 & -3.10 & $0.002^{*}$ \\
\hline Inflation & -0.00827 & -1.83 & $0.068^{* *}$ & -0.00948 & -0.25 & 0.802 \\
\hline Loan & 0.038901 & 3.40 & $0.001^{*}$ & 0.039719 & 2.74 & $0.006^{*}$ \\
\hline Capitalization & 0.53741 & 3.65 & $0.000^{*}$ & 0.418613 & 2.67 & $0.004^{*}$ \\
\hline Credit risk & -0.00287 & -1.96 & $0.050^{* *}$ & -0.008564 & -2.76 & $0.006^{*}$ \\
\hline Inefficiency & -0.04448 & -0.58 & 0.560 & -0.088331 & -3.61 & $0.000^{*}$ \\
\hline
\end{tabular}

Notes ${ }^{*},{ }^{* *},{ }^{* *}$ Significance at $1 \%, 5 \%$, and $10 \%$, respectively. 
Citation: Ferhi A (2017) Economic and Financial Profitability: A Comparative Study between Islamic and Conventional Banks during the Current Crisis. Intel Prop Rights. 5: 189. doi: 10.4172/2375-4516.1000189

Our results for these countries can be summarized as follows. First, during the period of the financial crisis, the financial profitability of Islamic and traditional banks decreases. Our results also demonstrated that the financial crisis adversely affects the profitability of conventional banks more than that of Islamic banks. We have also noticed that the insistence on the backing of real assets and the principle of loss and profit sharing increase fiscal discipline and provide more stability in the system during the current crisis. Moreover, it can be pointed out that the economic and financial profitability of Islamic and conventional banks is higher in the countries of the Gulf Cooperation Council (GCC) than that in those of South West Asia and North Africa. Among the main causes of the increase of the economic and financial profitability of the Gulf Cooperation Council (GCC) countries' banks compared to other countries, is that the GCC countries have quite a large number of banks with an extensive network of subsidiaries. Banks in these countries are financially sound, well capitalized and adopt modern banking services.

\section{References}

1. Siddiqi MN (2009) "Current financial crisis and Islamic economics". INSIGHTS 01: $141-150$

2. Khan FM, Porzio M (2009) "Islamic Finance and Banking in the European Union: a challenge". Printed and bound by MPG Books Group. UK.

3. Hasan MM, Dridi J (2010) "The effects of the global crisis on Islamic and conventional banks: A comparative study". IMF Working Papers, pp: 1-46.

4. Hamedian B (2013) "Financial Performance of Islamic Banks vs. Conventional Banks: The Case of Malaysia", (Doctoral dissertation, Eastern Mediterranean University (EMU)), Gazimağusa, North Cyprus, pp: 1-70.

5. Jordan S (2013) "Islamic banks and profitability: an empirical analysis of Indonesian banking", (Doctoral dissertation, University of Nottingham) pp: 1-77.

6. Alzoubi T (2015) "How Does Cash Holding Affect the Firm's Investment Decisions? Evidence from Jordan". World Journal of Social Sciences 5: 58-67.

7. Hassoune A (2002) "Islamic banks' profitability in an interest rate", cycle International Journal of Islamic Financial Services 4: 1-13.

8. Ansari S, Rehman A (2010) "Financial Performance of Islamic and Conventional Banks in Pakistan: A Comparative Study", International Conference on Islamic Economics and Finance.

9. Ansari S, Rehman K (2011) "Comparative Financial Performance of existing Islamic Banks and Contemporary Conventional Banks in Pakistan", International Conference on Islamic Economics and Finance.

10. Usman A, Khan KM (2012) "Evaluating the Financial Performance of Islamic and Conventional Banks of Pakistan: A Comparative Analysis", International Journal of Business and Social Science 3: 1-5.
11. Bashir A (2000) "Determinants of profitability and rates of return margins in Islamic banks: some evidence from the Middle East", Grambling State University Mimeo. Islamic Economic Studies 11: 1-27.

12. Sadaqat S, Akhtar MF, Ali K (2011) "An Analysis on the Performance of IPO A Study on the Karachi Stock Exchange of Pakistan", International Journal of Business and Social Science, 2: 275-285

13. Jaffar M, Manarvi I (2011) "Performance comparison of Islamic and Conventional banks in Pakistan", Global Journal of Management and Business Research, 11: 60-66.

14. Sehrish S et. al., (2012) "Financial Performance Analysis of Islamic Banks and Conventional Banks in Pakistan: A Comparative Study", Interdisciplinary Journal of Contemporary Research Business, 5.

15. Siraj K, Sudarsanan P (2012) "Comparative study on performance of Islamic banks and conventional banks in GCC region". J. Appl. Financ and Banking, 2: 123-161.

16. Abedifar P, Molyneux P, Tarazi A (2013) "Risks in Islamic Banking". Review of Finance.

17. Hassan MK, Bashir A (2003) "Determinants of Islamic banking profitability". Paper Presented at the ERF, Tenth Annual Conference, Marrakesh, Morocco, December pp: 1-31.

18. Pasiouras F, Kosmidou K (2007) "Factors influencing the profitability of domestic and foreign commercial banks in the European Union". Research in International Business and Finance, 21: 222-237.

19. Khediri BK, Khedhiri BH (2009) "Determinants of Islamic Bank Profitability in the MENA Region". Int J Monet Econ Financ 2: 409-426.

20. Olson D, Zoubi T (2008) "Using Accounting Ratios to distinguish between Islamic and Conventional Banks in the GCC Region", The International Journal of Accounting, 43: 45-65.

21. Beck T, Kunt DA, Merrouche O (2013) "Islamic vs. conventional banking business model, efficiency and stability", J Bank Financ 37: 443-447.

22. Bourkhis K, Nabi SM (2013) “Islamic and conventional banks' soundness during the 2001-2008 financial crisis" Review of Financial Economics, 22: 68-77.

23. Srairi SA (2010) "Cost and profit efficiency of conventional and Islamic banks in GCC countries”. J Prod Anal 34: 45-62.

24. Coyle B (2000) "Framework for Credit Risk Management" Chartered Institute of Bankers, United Kingdom.

25. Pirner D (2003) “Risk Management v českémbankovnictvi” Bankovnictví, no. 4.

26. Ferhi A, Chkoundali R (2015) "Credit Risk and Efficiency: Comparative Study between Islamic and Conventional Banks during the Current Crises" Journal of Behavioural Economics, Finance, Entrepreneurship, Accounting and Transport, 3: 47-56.https://doi.org/10.12691/jbe-3-1-6. 